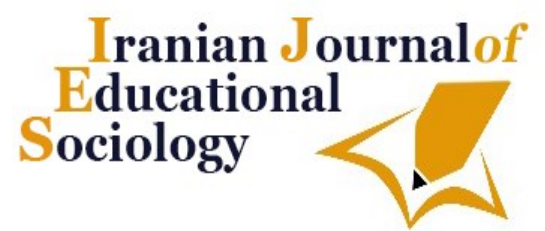

Iranian Journal of Educational Sociology

(Interdisciplinary Journal of Education)

Available online at: $\underline{\text { http://www.iase-idje.ir/ }}$

Volume 4, Number 1, March 2021

\title{
Designing a Suitable Leadership Model to Achieve New Missions of Higher Education
}

\author{
Minoo Taheri Rostami ${ }^{1}$, Amir Hosein Mohammad Davoudi ${ }^{2}$, Esmaeil Kavousi ${ }^{3}$ \\ 1. Department of Educational Management, College of Management, North Tehran Branch, Islamic Azad university, Tehran, Iran. \\ 2. PhD in Educational Management, Associate Professor Department of Educational Management, College of Humanities, Saveh \\ Branch, Islamic Azad University, Saveh, Iran. \\ 3. PhD in Cultural Management, Assistant Professor Professor Department of Cultural Management, College of Management, North \\ Tehran Branch, Islamic Azad university, Tehran, Iran.
}

\begin{abstract}
Article history:
Received: 2020/10/21

Accepted: 2021/03/21

Published: 2021/03/21
\end{abstract}

\section{Keywords:}

Suitable leadership, new missions, higher education

\begin{abstract}
Purpose: Considering the role of leadership in achieving the education missions, present research done with the aim of designing a suitable leadership model to achieve new missions of higher education.
\end{abstract}

Methodology: This study in terms of purpose was applied and in terms of implementation was exploratory combined (qualitative and quantitative). The research population in the qualitative part was the higher education experts and in the quantitative part were the personnel of Islamic Azad University of Tehran province in 2018-19 academic years. The research sample in the qualitative part according to the theoretical saturation principle were estimated 13 people who were selected by purposive sampling method and in the quantitative part according to Cochran's formula were estimated 385 people who were selected by cluster random sampling method with respect to classes (number of staff in universal branches). To collected data in the qualitative part used from interview and in the quantitative part used from researcher-made questionnaire (51 items) which the its content validity was confirmed by experts and its convergent validity by average variance extracted indicator was confirmed and its reliability was obtained by Cronbach's alpha method 0.84 . To analyze data were used from methods of open, axial and selective coding and exploratory factor analysis in SPSS-22 software.

Findings: The findings of the qualitative part showed that suitable leadership had 79 concepts, 63 categories and 7 dimensions and new missions of higher education dad 20 concepts, 15 categories and 3 dimensions. The findings of the quantitative part showed that the suitable leadership model to achieve new missions of higher education had 51 indicators or items and 15 components. Also, a suitable leadership model to achieve new missions of higher education was designed and approved by experts.

Conclusion: Based on the findings of the present study, higher education specialists and planners can design and implement programs to realization the new missions of higher education.

Please cite this article as: Taheri Rostami M, Mohammad Davoudi A H, Kavousi E. (2021). Designing a Suitable Leadership Model to Achieve New Missions of Higher Education. Iranian Journal of Educational Sociology. 4(1): 186-195.

\footnotetext{
* Corresponding Author: adavoudi838@yahoo.com
} 


\section{Introduction}

Higher education as a specialized field includes various subsystems and domains such as research, education, consulting, evaluation, curriculum, etc., the improvement of which requires a strategic orientation and the adoption of policies based on growth and evaluation in accordance with environmental developments and its use (Hu \& Dai, 2021). Higher education is one of the important infrastructures of the educational system of any country, whose task is to train specialized personnel in various fields, research and provide specialized services in various fields of science and technology to society. In recent years, the role of universities in the management and planning of countries has changed; So that the goal of the first generation of universities is direct education, the second generation of research-based education and education for research, the third generation of education to produce science and technology development in solving common problems, production of work and wealth creation and the fourth generation It seeks to train creative and innovative people (Abdi \& et al, 2017). The nature of higher education is evolving due to the advancement of information and communication technology, and these technologies have had a significant impact on the mission of universities in the dimensions of education and research (Amini \& et al, 2020). The mission of universities in the process of globalization is to adopt a future-oriented approach while identifying future opportunities, threats and challenges, formulate and implement the necessary strategies and goals to actively respond to change and continuous dynamism. Undoubtedly, the depiction of the favorable perspective of the university with the function of directing future behaviors and developments in the field of knowledge and education will affect the process of building the future of societies (Pourezzat \& et al, 2009). Rapid and abundant changes due to the phenomenon of globalization, especially in the fields of science and technology, and the emphasis on economics and knowledge-based development have caused higher education to be most affected by these changes (Shawe \& et al, 2019).

The most important challenges and necessities facing higher education that need to adopt appropriate strategies can include a dynamic and complex environment, the new mission of higher education, management and structure of higher education, academic independence, educational technology, access development, curriculum and faculty and students. In discussing the new mission of higher education, it should be said that universities should pay more attention to the views of society to understand their changing needs and expectations according to different factors and forces, and more eager to participate with industry, government and Other institutions provide higher education and even lead them (Secundo \& et al, 2017). Mission defines the meaning of organizational activities and practices under the vision and promotes the development of appropriate planning processes and preparation of the organization for the future. Also, the mission connects the direction and goals of the organization and integrates the behaviors and decisions of the organization in line with an appropriate goal (Kuzu \& et al, 2013). The mission that distinguishes one organization from another and represents all the programs, activities, costs and decisions of an organization that higher education missions include both general and specialized sections. The general missions of higher education refer to education, research, social services, and technology, but the specialized missions refer to the role-playing and leadership of universities in educating innovators (Freel \& et al, 2019). In fulfilling the missions of higher education, leadership has a critical role and the success of educational programs requires how it is organized and managed (Golden \& et al, 2019). Leadership means the ability to influence individuals or groups without coercion in order to achieve the goals of the organization, which affects the internal relations and its structure and makes employees eager to pursue the goals of the organization (Baker \& et al, 2020). Leadership strengthens individual and organizational goals and is the core and spirit of management that the degree of desirability of leadership significantly determines the success and failure of the organization (Luyten \& Bazo, 2019). One of the concerns of organizations, including higher education, is leadership. Because organizations are becoming more complex every day and organizational leaders face unpredictable problems that high flexibility helps them to solve problems and deal with turbulent environments (Ying \& Bin Ahmad, 2009). Leadership is one of the main processes of 
any organization and the productivity of the organization depends on the leadership style of managers and each organization needs a specific style of leadership according to its missions (Shao \& et al, 2017).

Little research has been done on achieving higher education missions and no research has examined the appropriate leadership model for achieving new educational missions. For example, the results of the research of Abdi et al. (2017) showed that the future curriculum in order to fulfill the missions of higher education, including modification and revision of texts, programs and teaching methods, development of basic sciences, tailoring levels and fields of study to the needs of production and employment and training of professionals. He was committed and an entrepreneur. Zolfagharzadeh \& Saadabadi (2014) while researching concluded that the mission of the university based on Islamic ideals includes humanization, intellectual independence and the realization of a culture of being able, building and building the future, ensuring the well-being of nations and the beacon of society and maintaining the Islamic Revolution. In another study, Hoseini \& Jahed (2013) reported that the mission of the university and academics included the primary mission, the cultural mission, the social mission, the educational mission, the mission of awareness and awareness, and the executive mission of university officials and planners. Also, the results of Amjadian et al. (2019) showed that the four components of improving and enhancing spiritual leadership in the management of educational centers, including faith, organizational commitment, meaning and piety. Gardner et al. (2018) concluded in a study that appropriate competencies for leadership and management in higher education included communication, project management, and strategic insight. In another study, Sedghy Boukany et al. (2018) reported that there is a significant relationship between effective leadership and strategic planning with human resource productivity in higher education institutions. In addition, the results of Moll \& Kretzschmar (2017) showed that the servant leadership approach in the university can improve faculty performance, facilitate excellence, creativity and innovation. Hamidifar et al. (2017) concluded that the four areas of leadership and management in the internationalization of higher education include analytical study of the environment, development of a coherent and purposeful strategic plan, implementation and organization of infrastructure, and continuous monitoring and evaluation. In another study, Soltani Sarvestani et al. (2017) reported that spiritual leadership in higher education had five domains: divine spirituality, existential spirituality, human spiritual excellence, organizational spiritual excellence, and sustainable global spiritual health.

Iran's higher education system, in line with global developments, has tried to strengthen the position of the higher education system at the national and global levels in the form of long-term goals and programs, and to meet the needs of society. This system, after the prosperity of universities in Europe and established through their modeling, today faces serious limitations and challenges. Therefore, reviewing and reforming the higher education system is essential for continuous adaptation to developments. Also, every organization should clearly formulate its visions and missions, and this is essential in the higher education organization of any society due to the important role that this organization has in the process of community development and achieving the desired future. Therefore, higher education, if it has clear visions and missions, can take steps towards them with appropriate leadership, for which more research is needed in this field. Therefore, the present study was conducted to design an appropriate leadership model to achieve new missions in higher education.

\section{Methodology}

This study was applied in terms of purpose and exploratory (qualitative and quantitative) in terms of implementation method. The research population was in the qualitative section of higher education experts and in the quantitative section of the staff of the Islamic Azad University of Tehran in the 2018-19 academic years. The research sample in the qualitative section according to the principle of theoretical saturation was estimated by 13 people who were selected by purposive sampling. In this sampling method, the researcher selects a number of experts according to the desired criteria, including a minimum 
master's degree, expertise in leadership and new missions in higher education, teaching experience in the higher education system, executive experience in the higher education system and Etc. chose. The study population in the quantitative section was 7516 people and the sample size according to Cochran's formula was 355 people who were selected according to the inclusion criteria of minimum undergraduate education by cluster random sampling and class observance (number of employees in university units). Due to the size of the research community in the quantitative section, in this sampling method, first of all units of the Islamic Azad University of Tehran, nine units were randomly selected (Central Tehran, North Tehran, Yadegar Imam, West Tehran, Ghods, Science and Research, Parand, South Tehran and Roodehen) and a number of samples were selected from each unit according to the population size. Due to the different volume of staff in the mentioned university units, 80 people from Central Tehran, 44 people in North Tehran, 30 people in Yadegar Imam, 17 people in West Tehran, 16 people in Ghods, 84 people in Science and Research, 17 people in Parand, 43 people in South Tehran And Roodehen 24 people were selected as the sample.

To conduct this research in the qualitative section, first documents and texts including books and printed and online articles about appropriate leadership and new missions of higher education were studied and with the help of supervisors and consultants, a number of interview questions were designed. These questions were presented in Table 1. Each of the 13 experts was interviewed individually and the important contents of each were recorded and a questionnaire was made based on it. Then, shortly after coordination with the Central Organization of the Islamic Azad University and preparing a list of staff in the university units of Tehran province, sampling was performed and the samples were researcher-made questionnaire (51 items) based on a five-point Likert scale (very low $=1$, low $=2$, I have no idea $=3$, too much $=4$ and too much $=5$ ) was scored, they replied. It should be noted that the ethical considerations in the present study included obtaining permission to record interviews, reassuring participants to keep information confidential, being voluntary and optional to participate in the study, and so on. The reliability of the interview was calculated by calculating the Cohen's Kappa coefficient of 0.636, which was significant at the level of 0.05 . Also, the content validity of the questionnaire was confirmed by experts and its convergent validity was confirmed by the extracted mean variance (AVE) index. In addition, the total reliability of the questionnaire was 0.84 by Cronbach's alpha method. In this study, open, axial and selective coding methods were used to analyze the data of the qualitative part and exploratory factor analysis method was used in the SPSS-22 software to quantitatively.

Interview questions: 1. what is your definition of a mission in higher education? 2. Why should higher education have a mission? 3. What factors are involved in identifying the mission in higher education? 4. What are the weaknesses of the missions defined in Iranian higher education? 5. What are the weaknesses of the missions defined in Iranian higher education? 6. In your opinion, what is the priority of Iran's higher education missions? 7. According to the international community, what missions are suitable for higher education in Iran? 8. What are the commonalities of Iran's higher education missions with other countries? 9. What are the differences between Iran's higher education missions and other countries? 10. What is your definition of a leader in the higher education system? 11. What are the characteristics of a successful and effective leader in the higher education system? 12. What do you know about the effective leadership style in the higher education system and why?

\section{Findings}

In the qualitative part of this study 13 people and in the quantitative part 355 people participated that the demographic characteristics of both qualitative and quantitative parts were presented in Table 1. 
Table1. Demographic characteristics of the qualitative and quantitative part of the research

\begin{tabular}{cccccc}
\hline & & \multicolumn{2}{c}{ Qualitative part } & \multicolumn{2}{c}{ Quantitative part } \\
\hline \multirow{2}{*}{ Attributes } & Levels & Abundance & Frequency & Abundance & Frequency \\
\hline \multirow{2}{*}{ Gender } & Female & 6 & $46 / 15 \%$ & 146 & $41 / 13 \%$ \\
\cline { 2 - 6 } & Man & 7 & $53 / 85 \%$ & 209 & $58 / 87 \%$ \\
\hline \multirow{2}{*}{ Age } & Less than 40 & 3 & $23 / 08 \%$ & 165 & $46 / 48 \%$ \\
\cline { 2 - 6 } & More than 40 & 10 & $76 / 92 \%$ & 190 & $53 / 52 \%$ \\
\cline { 2 - 6 } education & Masters & 0 & $0 \%$ & 192 & $54 / 11 \%$ \\
& Masters & 1 & $7 / 69 \%$ & 49 & $13 / 80 \%$ \\
\hline
\end{tabular}

The results of Table 1 showed that in both qualitative and quantitative sections more participants were male (53.85 and 58.87\%, respectively) and older than 40 years (76.92 and 53.52\%, respectively). In addition, most of their education was in the qualitative department of specialized doctorate (92.31) and in the quantitative department of master's degree (54.08\%). The results of open, axial, and selective coding to identify appropriate leadership were presented in Table 2.

Table2. Open, pivotal, and selective coding results to identify appropriate leadership

\begin{tabular}{|c|c|}
\hline $\begin{array}{l}\text { Selective coding } \\
\text { (later) }\end{array}$ & Axial coding (category) \\
\hline Ethical leadership & $\begin{array}{l}\text { 1. Honesty and straightforwardness, 2. Faithfulness to the covenant, 3. Humanitarianism, 4. Sacrifice, } 5 . \\
\text { Prohibition of nature, } 6 \text {. Justice-oriented, 7. Fairness, } 8 \text {. Moderation, 9. Non-discrimination, 10. Mercy } \\
\text { and Compassion, 11. Moral responsibility, 12. Trustworthiness, 13. Merit in employment }\end{array}$ \\
\hline $\begin{array}{l}\text { Emotional } \\
\text { leadership }\end{array}$ & $\begin{array}{c}\text { 1. Resolving conflicts and conflicts, 2. Ability and skill to negotiate, 3. Importance to the emotional needs } \\
\text { of others, 4. Focusing on feelings and emotions, } 5 \text {. Effective listener, } 6 \text {. Eager for free two-way } \\
\text { communication, 7. Compatibility and adaptability, and } 8 \text { Pay attention to organizational happiness and } \\
\text { vitality }\end{array}$ \\
\hline $\begin{array}{l}\text { Service-oriented } \\
\text { leadership }\end{array}$ & $\begin{array}{l}\text { 1. Responsibility for subordinate performance, 2. Building trust in others, 3. Serving others before serving } \\
\text { oneself, 4. Steadfastness, } 5 \text {. Healing, } 6 \text {. Committed to the growth and development of individuals, and } 7 . \\
\text { Paying attention to education. Lifetime }\end{array}$ \\
\hline $\begin{array}{l}\text { Originalism } \\
\text { leadership }\end{array}$ & $\begin{array}{l}\text { 1. Transparency in organizational communication, } 2 \text {. Healthy and positive organizational climate, } 3 \text {. } \\
\text { Adherence to ethics, } 4 \text {. Creating a transparent and secure organizational environment, } 5 \text {. Observance of } \\
\text { ethical codes, } 6 \text {. Promoting a culture based on honest confession of mistakes, } 7 \text {. Self-awareness Leadership } \\
\text { towards their strengths and weaknesses and } 8 \text {. Respecting the positive and negative opinions of others }\end{array}$ \\
\hline $\begin{array}{l}\text { transformational } \\
\text { leadership }\end{array}$ & $\begin{array}{l}\text { 1. Influence, 2. Criticism, 3. Capable of creating a great vision for the future, 4. Mental motivation, } 5 . \\
\text { Inspiring others, 6. Eager to train future leaders, and 7. Encouraging others }\end{array}$ \\
\hline $\begin{array}{l}\text { Participatory } \\
\text { leadership }\end{array}$ & $\begin{array}{c}\text { 1. Participation in work decisions, 2. Consultative participation, 3. Formal participation, 4. Informal } \\
\text { participation, 5. Intellectual, 6. Collective wisdom, 7. Empowerment of human resources, 8. Promoting a } \\
\text { culture of working with others, 9. Attracting and using From experts and } 10 \text { guarantees of trust and } \\
\text { participation of more stakeholders }\end{array}$ \\
\hline $\begin{array}{l}\text { Spiritual } \\
\text { leadership }\end{array}$ & $\begin{array}{c}\text { 1. Having insight, insight and positive attitude, 2. Trust in sanctity, 3. Creating a spiritual and spiritual } \\
\text { atmosphere, 4. Committed to the progress of the Islamic system, 5. Strengthening religious beliefs in } \\
\text { individuals, 6. Believing in forgiveness instead of hatred and revenge, 7. Kindness and good-heartedness, } 8 . \\
\text { The exaltation of the human soul, 9. Untying the problems of individuals and 10. Fighting corruption, } \\
\text { gangsterism and factionalism }\end{array}$ \\
\hline \multicolumn{2}{|c|}{$\begin{array}{l}\text { The results of Table } 3 \text { showed that for proper leadership } 79 \text { concepts, } 63 \text { categories and } 7 \text { dimensions } \\
\text { including ethical leadership ( } 15 \text { concepts in } 13 \text { categories), emotional leadership (10 concepts in } 8 \\
\text { categories), service-oriented leadership ( } 8 \text { concepts in } 7 \text { categories), Originalist leadership (10 concepts in } \\
8 \text { categories), transformational leadership ( } 8 \text { concepts in } 7 \text { categories), participatory leadership ( } 16 \\
\text { concepts in } 10 \text { categories) and spiritualist leadership ( } 12 \text { concepts in } 10 \text { categories) were identified, The } \\
\text { results of open, pivotal and selective coding to identify new higher education mis sions were presented in } \\
\text { Table } 3 \text {. }\end{array}$} \\
\hline
\end{tabular}


Table3. Open, pivotal, and selective coding results to identify new higher education missions

\begin{tabular}{|c|c|}
\hline $\begin{array}{c}\text { Selective coding } \\
\text { (later) }\end{array}$ & Axial coding (category) \\
\hline $\begin{array}{c}\text { Knowledge } \\
\text { creation }\end{array}$ & $\begin{array}{l}\text { 1. Providing educational opportunities and lifelong learning for all, 2. Access to knowledge and information } \\
\text { for all, 3. Production of knowledge as a continuous task, 4. Attracting and retaining efficient professors, } 5 \text {. } \\
\text { Training a generation of top scientists and professionals, } 6 \text {. Establishing Security in the field of production and } \\
\text { exchange of information and 7. Providing university education related to practical and technological fields }\end{array}$ \\
\hline $\begin{array}{l}\text { Educating } \\
\text { developed } \\
\text { human beings }\end{array}$ & $\begin{array}{l}\text { 1. Raising a generation of global citizens, 2. Educating capable citizens in order to advance the country's } \\
\text { goals, 3. Aligning education with the needs of the labor market and 4. Strengthening the social, } \\
\text { communication, emotional and cultural literacy of citizens }\end{array}$ \\
\hline $\begin{array}{l}\text { Encourage } \\
\text { creativity and } \\
\text { initiative }\end{array}$ & $\begin{array}{l}\text { 1. Emphasis on applied research and development in the higher education system, 2. Attention to intellectual } \\
\text { property, 3. Improving the living standards of individuals in the national and global community, and } 4 \text {. } \\
\text { Leading the frontiers of knowledge and technology }\end{array}$ \\
\hline
\end{tabular}

The results of Table 3 showed that for the new missions of higher education 20 concepts, 15 categories and 3 dimensions including knowledge creation (10 concepts in 7 categories), training of developed human beings ( 5 concepts in 4 categories) and encouraging creativity and initiative ( 5 concepts in 4 categories) were identified. Pebble diagram was presented in Figure 1 to identify the number of factors in the appropriate leadership model to achieve new missions in higher education.

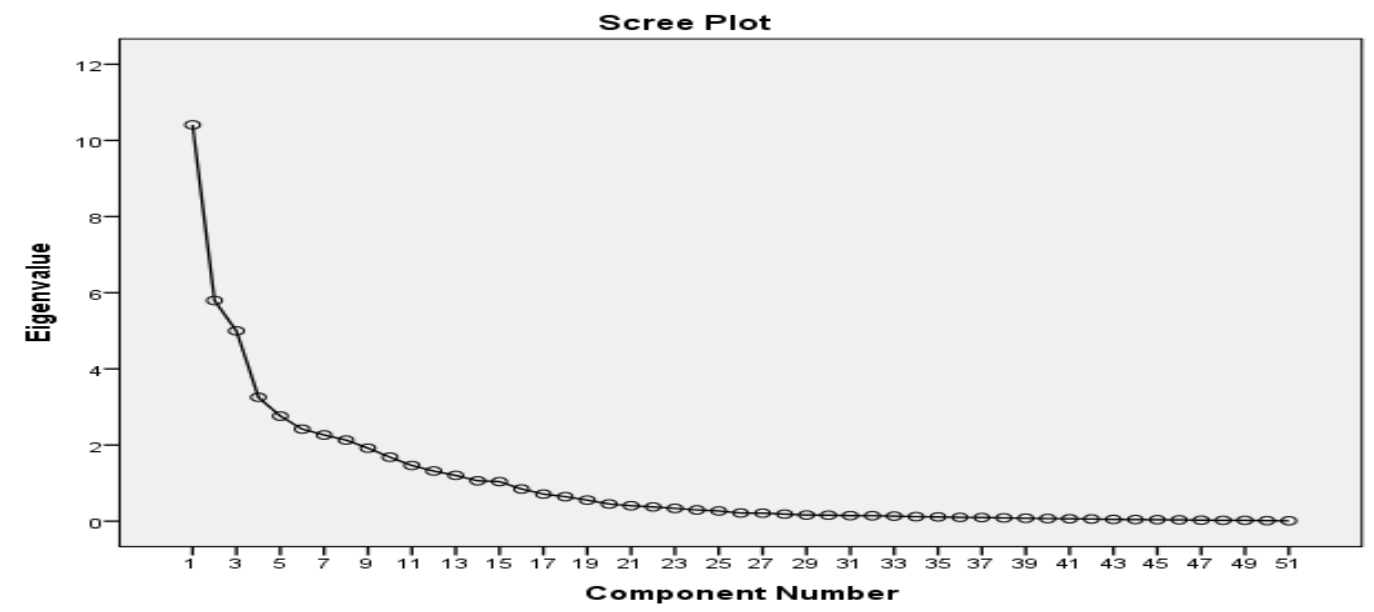

Figure1. Pebble diagram to identify the number of factors of the appropriate leadership model to achieve new missions in higher education

The results of Figure 1 showed that there were 15 factors or components for the appropriate leadership model to achieve new missions in higher education. The results of exploratory factor analysis to identify the appropriate leadership model to achieve new missions in higher education are presented in Table 4.

Table4. Results of exploratory factor analysis to identify the appropriate leadership model to achieve new missions in higher education

\begin{tabular}{ccccccc}
\hline Dimensions & Components & $\begin{array}{c}\text { Number of } \\
\text { items or } \\
\text { indexes }\end{array}$ & $\begin{array}{c}\text { Factor } \\
\text { load }\end{array}$ & $\begin{array}{c}\text { Effect rate } \\
\text { (percentage of } \\
\text { variance) }\end{array}$ & $\begin{array}{c}\text { Reliability } \\
\text { (Cronbach) }\end{array}$ & $\begin{array}{c}\text { Validity } \\
\text { (AVE) }\end{array}$ \\
\hline Ethical leadership & Honesty & 3 & $0 / 68$ & $9 / 02$ & $0 / 75$ & $0 / 62$ \\
\hline $\begin{array}{c}\text { Emotional } \\
\text { leadership }\end{array}$ & Justice & 4 & $0 / 71$ & $8 / 74$ & $0 / 79$ & $0 / 53$ \\
\hline $\begin{array}{c}\text { Social and } \\
\text { communication skills }\end{array}$ & Guidance & 3 & $0 / 67$ & $8 / 32$ & $0 / 55$ \\
\hline leadership & Committed to service & 4 & $0 / 57$ & $7 / 76$ & $0 / 79$ & $0 / 70$ \\
\hline Originalism & responsiveness & 3 & $0 / 73$ & $5 / 30$ & $0 / 66$ \\
\hline
\end{tabular}




\begin{tabular}{|c|c|c|c|c|c|c|}
\hline leadership & & & & & & \\
\hline & Inner moral aspects & 3 & $0 / 68$ & $5 / 00$ & $0 / 71$ & $0 / 52$ \\
\hline \multirow[t]{3}{*}{$\begin{array}{c}\text { transformational } \\
\text { leadership }\end{array}$} & Has an ideal influence & 3 & $0 / 66$ & $4 / 94$ & $0 / 80$ & $0 / 73$ \\
\hline & $\begin{array}{c}\text { Inspirational } \\
\text { motivation }\end{array}$ & 3 & $0 / 70$ & $4 / 94$ & $0 / 81$ & $0 / 64$ \\
\hline & Stimulation of culture & 3 & $0 / 57$ & $4 / 88$ & $0 / 79$ & $0 / 53$ \\
\hline \multirow[t]{2}{*}{$\begin{array}{c}\text { Participatory } \\
\text { leadership }\end{array}$} & $\begin{array}{c}\text { Adopt a knowledge- } \\
\text { based strategy }\end{array}$ & 4 & $0 / 67$ & $3 / 79$ & $0 / 76$ & $0 / 58$ \\
\hline & Group building & 4 & $0 / 61$ & $3 / 57$ & $0 / 73$ & $0 / 62$ \\
\hline \multirow[t]{3}{*}{ Spiritual leadership } & $\begin{array}{l}\text { Pay attention to } \\
\text { spirituality }\end{array}$ & 4 & $0 / 79$ & $3 / 57$ & $0 / 80$ & $0 / 62$ \\
\hline & Deep down & 3 & $0 / 66$ & $3 / 56$ & $0 / 75$ & $0 / 60$ \\
\hline & Total & 51 & --- & $85 / 71$ & $0 / 84$ & --- \\
\hline
\end{tabular}

The results of Table 4 showed that appropriate leadership had 51 indicators or items and 15 components, all of which had a significant factor load at the level of 0.05 and together were able to explain $85.71 \%$ of the total variance. Also, their reliability was confirmed by calculating Cronbach's alpha coefficient due to greater than 0.70 and their convergent validity was confirmed by calculating the mean variance extracted due to greater than 0.50 . According to the above findings, a suitable leadership model to achieve new missions of higher education was presented in Figure 2.

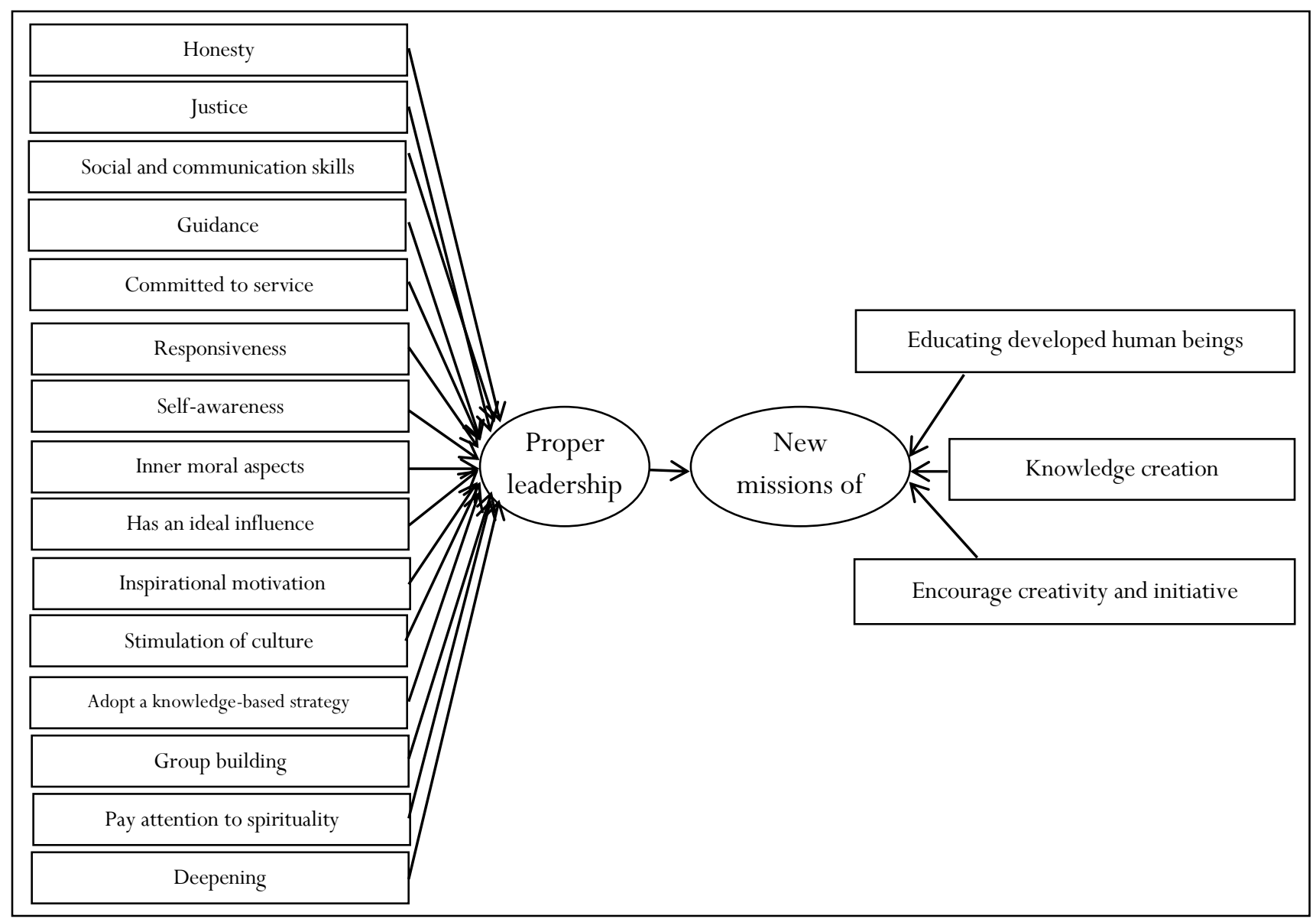

Figure2. Model of professional competence of principals based on the development of creativity and innovation in primary schools 


\section{Discussion}

Today, organizations (especially higher education) face major challenges and to meet this challenge, the realization of new missions of higher education and appropriate leadership for it can play an effective role and lead to the growth and development of societies. Therefore, the present study was conducted to design an appropriate leadership model to achieve new missions in higher education. The findings of the qualitative section showed those appropriate leadership 79 concepts, 63 categories and 7 dimensions including ethical leadership, emotional leadership, service leadership, original leadership, transformational leadership, participatory leadership and spiritual leadership and new missions of higher education 20 concepts, 15 categories and 3 dimensions It included creating knowledge, educating developed people, and encouraging creativity and initiative. Also, the findings of the quantitative section showed that the appropriate leadership model to achieve new missions of higher education had 51 indicators or items and 15 components that their factor load, validity and reliability were appropriate and based on that model was designed and approved by experts, Although no research has been found on appropriate leadership to achieve new missions in higher education, but studies on the dimensions and components of new missions in higher education and leadership have been conducted that the results of this study are in some ways consistent with their results. For example, the results of this study in the field of dimensions and components of higher education missions with the research of Abdi, et al (2017), Zolfagharzadeh \& Saadabadi (2014) and Hoseini \& Jahed (2013) and in the field of dimensions and components of appropriate leadership with the research of Amjadian, et al (2019), Gardner, et al (2018), Sedghy Boukany, et al.(2018), Moll \& Kretzschmar (2017), Hamidifar, et al (2017) and Soltani Sarvestani, et al (2017).

In interpreting the dimensions of appropriate leadership, it can be said that ethical leadership with two components of honesty and justice shows appropriate behavior through actions and interpersonal relationships and promoting these actions and behavior through two-way relationships, strengthening and decision-making in employees by managers. Undoubtedly, the highest quality of leadership is honesty and justice, and leaders succeed when they adhere to their core values and beliefs, and this would not be possible without ethics. Ethical leaders respect the human rights and dignity of others, take into account the needs of employees and act fairly, based on which trust in the organization increases and employees better understand organizational practices and perform their duties with energy and passion. And they act more cheerfully. Emotional leadership demonstrates empathy-based behavior with two components of social and communication skills and leadership. Emotional intelligence is a prerequisite for successful leadership and the tasks of the leader are planning, organizing, directing, supervising, controlling and leading, which cannot be achieved without an effective communication system in the organization and this type of leadership connects the fabric of an organization. It becomes organizational integrity and unity. Serviceoriented leadership with two components committed to service and accountability represents leaders who have characteristics such as service, identifying the needs of members of the organization, accountable and ethical, and humbly serve followers and employees, and the people who work with them show the highest level of commitment. Service-oriented leadership in higher education can lead human resources, both faculty and staff, to deliver more effective performance, due to its human orientation and low power, and its focus on facilitating excellence, creativity, and innovation. Therefore, service-oriented leadership in the higher education system is important and it can improve the performance of the organization. Originalist leadership with its two components of self-awareness and internal ethical aspects is a metaphor for the effectiveness of professional, ethical, and effective and informed methods in educational management. This type of leadership is based on knowledge and awareness of values and their skillful implementation and emphasizes the self-control and self-awareness of the leader and followers. In the original leadership process, there is an open, transparent, friendly and trusting relationship between leader and followers. The higher education system can create a healthy and favorable organizational climate and provide the ground for growth and development by improving motivation, morale and job satisfaction. Transformational 
leadership refers to behaviors that motivate employees to act beyond their formal expectations and to disregard their personal interests for the betterment of the organization with three components: ideal influence, inspirational motivation, and stimulation of culture. Transformational leadership creates fundamental change in employees by promoting their need for advancement and self-actualization. Organizations today are looking for leaders who can formulate a vision and have the charisma to achieve it, and transformational leaders have such characteristics. Thus, with such leaders, the higher education system can hope to fulfill new missions, including modernity and innovation. Participatory leadership with two components of adopting knowledge-based strategy and grouping is one of the most important human tendencies of leadership in educational institutions. This leadership style is a model of democracy that focuses on participation in decision-making in the education system. Participatory leaders have the ability to create change and movement, mobilize purposeful people for growth and development, motivate and inspire, and enjoy sharing their ideas with others. Thus, in recent years, participatory leadership has helped the higher education system achieve its goals of encouraging and supporting the participatory spirit, including knowledge creation and the training of ideal citizens. Spiritualist leadership refers to leaders with two components of attention to spirituality and insight, which increase employees' inner motivations by creating opportunities for them to achieve deep spiritual meanings and a sense of strength in their work. Spiritual leaders are very moral and do not compromise when their core values are threatened, but challenge them instead of adapting to the ideas and thoughts of others. Such leaders provide the spiritual survival of the members of the organization by using the values, attitudes, and behaviors that are necessary to motivate themselves and others internally.

In interpreting the dimensions of the new missions of higher education, it can be said that knowledge creation is a collective and practical phenomenon when there is full access to knowledge and people have a high ability to integrate ideas and experiences. The most important mission of higher education is knowledge creation, which provides knowledge, scientific, social, political, material and similar needs for society by producing knowledge, and with proper management, provides the conditions and grounds for knowledge creation. Also, the development of developed human beings refers to the training of citizens to understand the rights and responsibilities of their profession, to participate in discourses and social forums, to seek to improve their knowledge, skills and attitudes, and to be able to critique and evaluate information. Higher education should not be happy with the issuance of bachelor's, masters and doctoral degrees, but should train developed people or professional citizens to make a difference in society and share their knowledge, skills and insights with people in the community. In addition, encouraging creativity and initiative encourages people to research, creativity and initiative to use new knowledge to provide better services to society. There must be creativity and innovation in all dimensions and fields, such as the production and dissemination of science and knowledge, the training of specialized forces, the solution of community problems, and the development of cultural heritage. In higher education, innovation and creativity must be present in students, faculty, curricula, textbooks, educational space, teaching aids, and in general in all educational, cultural, and educational dimensions in order for the goals of higher education to be well achieved.

The most important limitations of the research included the limitation of the research community to the staff of the Islamic Azad University of Tehran, the low willingness of some people to participate in the research, the use of researcher-made tools in the quantitative section and possible tendencies and prejudices in responding to interviews and questionnaires. Therefore, one of the most important research suggestions is to conduct this research on the staff of Islamic Azad University of other provinces, staff of other universities including government, non-profit, Payame Noor and applied science, trying to persuade people to participate in research and use a researcher-made questionnaire in other He pointed out the researches and review of its psychometric indicators or even the construction of other questionnaires in this field. 


\section{References}

Abdi H, Mirshah Jafari SE, Nili MR, Rajaeipour S. (2017). An explanation of the future curricula toward realizing the visions and missions of Iranian higher education in horizon of 2025. Journal of Higher Education Curriculum. 8(16):59-88.

Amini N, NasrEsfahani A R, Zamani B E, Tork Ladani B. (2020). Meta-analysis of the impact of the use of information and communication technology on educational and research performance of faculty members of the universities. Technology of Education Journal. 14(2):231-245.

Amjadian K, TaghipoorZahir A, Zamani Moghadam A. (2019). A model for the school management in primary school, based on spiritual leadership. Journal of School Administration. 7(2):124-147.

Baker C M, Crabtree G, Anderson K. (2020). Student pharmacist perceptions of learning after strengths-based leadership skills lab and escape room in pharmacy practice skills laboratory. Currents in Pharmacy Teaching and Learning. 12(6): 724-727.

Freel M, Persaud A, Chamberlin T. (2019). Faculty ideals and universities' third mission. Technological Forecasting and Social Change. 147:10-21.

Gardner J, Chongwony L, Washington T. (2018). Investigating instructional design management and leadership competencies: A Delphi study. Online Journal of Distance Learning Administration. 21(1):13-26.

Golden S H, Bass E, Berry S, et al. (2019). Building leadership capacity for mission execution in a large academic department of medicine. The American Journal of Medicine. 132(4):535-543.

Hamidifar F, Yusoff K, Ebrahimi M. (2017). Leadership and management in the internationalization of higher education. Research and Planning in Higher Education. 23(1):49-71.

Hoseini SM, Jahed H. (2013). Explain the mission of the university and academics against soft war. Biquarterly Journal of Soft Power Studies. 3(9):41-62.

$\mathrm{Hu}$ Y, Dai K. (2021). Foreign-born Chinese students learning in China: (Re)shaping intercultural identity in higher education institution. International Journal of Intercultural Relations. 80: 89-98.

Kuzu O H, Gokbel H, Gules H K. (2013). Developing sustainable relations with internal and external stakeholders in universities: Vision and mission views. Procedia - Social and Behavioral Sciences. 103:281-289.

Luyten H, Bazo M. (2019). Transformational leadership, professional learning communities, teacher learning and learner centred teaching practices; Evidence on their interrelations in Mozambican primary education. Studies in Educational Evaluation. 60:14-31.

Moll J, Kretzschmar L. (2017). An investigation of the suitability of a servant leadership model for academic group leaders at German universities. Journal of Leadership Education. 16(2):166-182.

Pourezzat A A, Khastar H, Taheri Attar G h, et all. (2009). Optimal model of design the higher education of universities and institutions of Iran in the era of globalization. Daneshgah-E-Eslami. 12(4):3-22.

Secundo G, Perez S E, Martinaitis Z, Leitner K H. (2017). An Intellectual Capital framework to measure universities' third mission activities. Technological Forecasting and Social Change. 123:229-239.

Sedghy Boukany N S, Abbaszadeh M M, Ghalavand H, Hassani M. (2018). Analyzing multiple relationships of effective leadership, strategic planning by with human resource efficiency of higher education institutions in West Azerbaijan province. The Journal of Productivity Management. 12(2):31-69.

Shao Z, Feng Y, Hu Q. (2017). Impact of top management leadership styles on ERP assimilation and the role of organizational learning. Information \& Management. 54(7):902-919.

Shawe R, Horan W, Moles R, O,Regan B. (2019). Mapping of sustainability policies and initiatives in higher education institutes. Environmental Science \& Policy. 99:80-88.

Soltani Sarvestani J, Salehi M, Gholtash A, Nadi MA. (2017). Confirmatory factor analysis of the spiritual leadership model in higher education. Journal of New Approaches in Educational Administration. 8(32):19-42.

Yiing LH, Bin Ahmad KZ. (2009). The moderating effects of organizational culture on the relationships between leadership behaviour and organizational commitment and between organizational commitment and job satisfaction and performance. Leadership and Organization Development Journal. 30:53-86.

Zolfagharzadeh M M, Saadabadi A A. (2014). Redefining the main functions of the university in society based on Islamic ideals in Imam Khomeini's thought. Basij Strategic Studies Quarterly. 17(65):5-31. 